\title{
ROOT-KNOT NEMATODE (MELOIDOGYNE JAVANICA) \\ - DEFICIT IRRIGATION INTERACTIONS ON EGGPLANT CROPPED UNDER OPEN FIELD CONDITIONS
}

\author{
Muwaffaq KARAJEH ${ }^{1 *}$, Osama MOHAWESH ${ }^{2}$ \\ ${ }^{1}$ Plant Protection and IPM Department \\ ${ }^{2}$ Plant Production Department, Faculty of Agriculture \\ Mutah University, P.O. Box 7, Karak, 61710, Jordan \\ Received: March 2016; Accepted: June 2016
}

\begin{abstract}
To investigate the influence of deficit irrigation on the root-knot nematode, Meloidogyne javanica, and its interaction with the eggplant crop, field experiments were conducted at two drip-irrigated agricultural areas in Jordan. Effects of limiting irrigation levels to 80, 60, 40 and 20\% of the field capacity (FC) were compared with full irrigation (100\%) treatment. Growth of eggplant plants was greatly reduced at irrigation levels of 40 and $20 \% \mathrm{FC}$ at one field location, suggesting that the influence of deficit irrigation is field-dependant. Fruit yield was similar at all irrigation levels, except at $20 \%$ level, where a lower yield was noticed compared to $100 \%$ irrigation. Root galling of eggplant caused by the nematode was significantly lower at irrigation levels of 20 and $40 \%$ than 80 and $100 \%$ of FC, but was field-dependant at $60 \%$ of FC. The final nematode population was obviously lower at irrigation levels of 20,40 and $60 \%$ than 80 and $100 \%$. Thus, deficit irrigation to levels of 40 or $60 \%$ of FC can be utilised for the management of $M$. javanica infection in eggplant under field conditions.
\end{abstract}

Key words: eggplant roots, population $M$. javanica, water deficit

\section{INTRODUCTION}

Plant-parasitic nematodes are important plant pests (Sasser \& Freckman 1987). They develop on the extensive root systems of both annual and perennial crops, damage the root system severely and cause economic losses of more than $12 \%$ annually worldwide (Sasser 1987); about 5\% of the crop losses are caused by a widely distributed group of plant-parasitic nematodes that are usually known as the root-knot nematodes (Sasser et al. 1983; Sasser \& Freckman 1987; Siddiqui et al. 2003). Plants infected by root-knot nematodes show stunted growth accompanied by symptoms of severe deficiency of some nutritional elements, substantially reduced nutrient and water uptake, and yield amount and quality (Khyami-Horani \& AlBanna 2006; Strajnar et al. 2012).
Soil moisture is an important factor affecting nematode development and infection (Wallace 1963; Duncan et al. 1998; Hunter 2000). Increasing water stress decreases the water potential from -1 to -10 bars around the root-knot nematode, Meloidogyne javanica (Treub 1885; Chitwood 1949), which reduces the percentage of eggs hatching and increases the percentage of second-stage juvenile mortality (Mohwesh \& Karajeh 2013). Therefore, water stress ensures that nematodes remain confined to the irrigated and highly rained agricultural areas worldwide (Sasser et al. 1983), such as the irrigated agricultural regions of Jordan (AbuGharbieh et al. 2005; Karajeh \& Al-Ameiri 2010). For coping with water shortage and scarce supplies, deficit irrigation, defined as application of water below the full requirement of the crop, is an important tool that achieves the goal of reducing the amount 
of water required for irrigation (Fereres \& Soriano 2007). Deficit irrigation has been widely investigated as a valuable and sustainable production strategy in dry regions (Geerts \& Raes 2009). Although deficit irrigation has been effectively used in fruit tree orchards (Zegbe et al. 2004; Shin 2005; Kriedemann \& Goodwin 2009; Mahadeen et al. 2011), there is potential for improving water productivity in many field crops, and there is sufficient information available for devising the best deficit irrigation strategy in many situations (Fereres \& Soriano 2007). Also, deficit irrigation could have the ability to control soil moisture-sensitive plant pests and diseases (Shin 2005; Mohwesh \& Karajeh 2013). Deficit irrigation used at a rate of 80 and $60 \%$ of full irrigation had controlled the root-knot nematode, $M$. javanica, in tomato and eggplant (Solanum melongena L.) under controlled environmental conditions (Mohwesh \& Karajeh 2013). Thus, deficit irrigation can be utilised to control some plant pests and diseases, especially those that are affected by irrigation regimes and are moisture-dependant, as an extra benefit (Shin 2005).

Therefore, the main objectives of this study are to compare the effects of deficit irrigation regimes [20, 40, 60 and $80 \%$ of field capacity (FC)] with those of full irrigation (100\% of FC) on some parameters of eggplant growth and population of $M$. javanica under open field conditions.

\section{MATERIALS AND METHODS}

Two field experiments were conducted in two different drip-irrigated agricultural areas: Ghor esSafi region (receives about $80 \mathrm{~mm}$ of annual rainfall and has silty loam soil; situated $418 \mathrm{~m}$ below sea level) of southern Ghors; and Karak Valley region (receives about $200 \mathrm{~mm}$ of annual rainfall and has clay loam soil; situated about $200 \mathrm{~m}$ above sea level) of semi-Ghor area in Karak province of Jordan. Field experiments were conducted during the eggplant growing seasons, from mid-September 2012 to mid-March 2013 in Ghor es-Safi, and from mid-February to mid-July 2013 in Karak Valley. Average minimum and maximum regional air temperatures at Ghor es-Safi and Karak Valley during the course of the experiments ranged between 12 and $32{ }^{\circ} \mathrm{C}$ and 10 and $28^{\circ} \mathrm{C}$, respectively. Two field populations of root-knot nematodes were identified as $M$. javanica by observing the perineal pattern of females and measuring the length of second-stage juveniles (Barker et al. 1985), and confirmed by Meloidogyne species-specific sequence characterised amplified region-polymerase chain reactionbased test (Karajeh 2004).

Eggplant cv. 'Classic', a susceptible cultivar to $M$. javanica, was selected for cropping in both field experiments. Three-week-old seedlings (averaging $7 \mathrm{~cm}$ in height) were transplanted $80 \mathrm{~cm}$ apart into black plastic mulch-covered rows, with inter-row spacing of $150 \mathrm{~cm}$. When the plants were 4 weeks old, the following treatments were applied in a randomised complete block design. Each treatment involved 25 plants per plot (row), replicated three times (three blocks). Irrigation was done using the drip irrigation system when $50 \%$ of total water available for full irrigation $(100 \%)$ was depleted (readily available water $=50 \%$ of available water). The irrigation regimes gave irrigation $80,60,40$ and $20 \%$ of FC to the amount of treatment based on the full irrigation treatment.

At the end of the experiment (after 15 weeks from the date of transplanting), all the plants (about 25 plants per plot) were dug out from the fields. Dry weights of shoots and roots (after air-drying of the samples on an electrical oven at $70{ }^{\circ} \mathrm{C}$ for 5 days), and fruit yield were assessed. Root galling index was evaluated on a scale of 0-5 as follows: 0 no galling; 1. 1-2 galls; 2. 3-10 galls; 3. 11-30 galls; 4. 31100 galls; and 5. over 100 galls (Taylor \& Sasser 1978). Representative rhizospheric soils [five random samples (500 g per sample) per plot] were collected from each treatment for nematode extraction using Baermann's method (Whitehead \& Hemming 1965; Hussey \& Barker 1973) to estimate the final nematode population (Pf) density rather than determining the reproductive factor of the nematode, since the initial nematode population was very small to be detected despite extensive sampling at the beginning of the experiment.

Data were analysed statistically using the general linear model procedure (SPSS 11.5 software; SPSS Inc., Chicago, IL, USA). Duncan's multiple range test was used for separation of means at a prob- 
ability level of 0.05 . Significance of main factors and interactions were tested at a probability level of 0.05 .

\section{RESULTS}

There was reduction in shoot and root dry weights when irrigation levels of 20 and $40 \%$ were used, but irrigation at 60 and $80 \%$ levels did not significantly change $(\mathrm{p} \leq 0.05)$ the shoot and root dry weights when compared with the full (100\%) irrigation level in the field conditions of Ghor es-Safi (Table 1). However, no significant differences were found in shoot and root dry weights between the different irrigation levels in the field conditions of Karak Valley. Eggplant fruit yield was obviously similar for all irrigation levels, except the $20 \%$ level, where yield lower than that of $100 \%$ level was noticed (Table 1).

Root galling index of eggplant was significantly ( $\leq 5.05$ ) lower for plants irrigated at 20, 40 and $60 \%$ levels than plants irrigated at 80 and $100 \%$ levels in the field conditions of Ghor es-Safi, but plants irrigated at $60 \%$ levels did not differ in their root galling index from those irrigated at 80 and $100 \%$ levels (Fig. 1A). The final nematode population at the end of the eggplant growing season was lower in the rhizospheric soil taken from fields irrigated at 20, 40 and $60 \%$ levels than fields irrigated at 80 and $100 \%$ of FC under the two field conditions (Fig. 1B).

Table 1. Shoot and root dry weight and fruit yield of eggplant cropped under two field conditions (Field 1 - Ghor esSafi region, Field 2 - Karak Valley of Jordan)

\begin{tabular}{ccccccc}
\hline \multirow{2}{*}{$\begin{array}{c}\text { Irrigation } \\
\text { regimes }\end{array}$} & \multicolumn{2}{c}{$\begin{array}{c}\text { Shoot dry weight } \\
\text { (g/plant) }\end{array}$} & \multicolumn{2}{c}{$\begin{array}{c}\text { Root dry weight } \\
\text { (g/plant) }\end{array}$} & \multicolumn{2}{c}{$\begin{array}{c}\text { Fruit Yield } \\
\text { (kg/plant })\end{array}$} \\
\cline { 2 - 7 } & Field 1 & Field 2 & Field 1 & Field 2 & Field 1 & Field 2 \\
\hline $20 \%$ & $111.8^{2} \mathrm{~b}^{3}$ & $22.9 \mathrm{a}$ & $50.1 \mathrm{~b}$ & $38.1 \mathrm{a}$ & $0.80 \mathrm{~b}$ & $0.30 \mathrm{~b}$ \\
\hline $40 \%$ & $142.9 \mathrm{~b}$ & $21.1 \mathrm{a}$ & $62.3 \mathrm{~b}$ & $31.6 \mathrm{a}$ & $0.96 \mathrm{ab}$ & $0.39 \mathrm{ab}$ \\
\hline $60 \%$ & $166.1 \mathrm{a}$ & $20.4 \mathrm{a}$ & $70.1 \mathrm{ab}$ & $30.2 \mathrm{a}$ & $1.00 \mathrm{ab}$ & $0.48 \mathrm{ab}$ \\
\hline $80 \%$ & $157.3 \mathrm{a}$ & $25.5 \mathrm{a}$ & $75.7 \mathrm{a}$ & $23.5 \mathrm{a}$ & $1.04 \mathrm{ab}$ & $0.65 \mathrm{ab}$ \\
\hline $100 \%$ & $162.3 \mathrm{a}$ & $29.7 \mathrm{a}$ & $67.1 \mathrm{ab}$ & $36.4 \mathrm{a}$ & $1.11 \mathrm{a}$ & $0.88 \mathrm{a}$ \\
\hline
\end{tabular}

The means within columns followed by the same letters are not significantly different at 0.05 probability level using DMRT test.
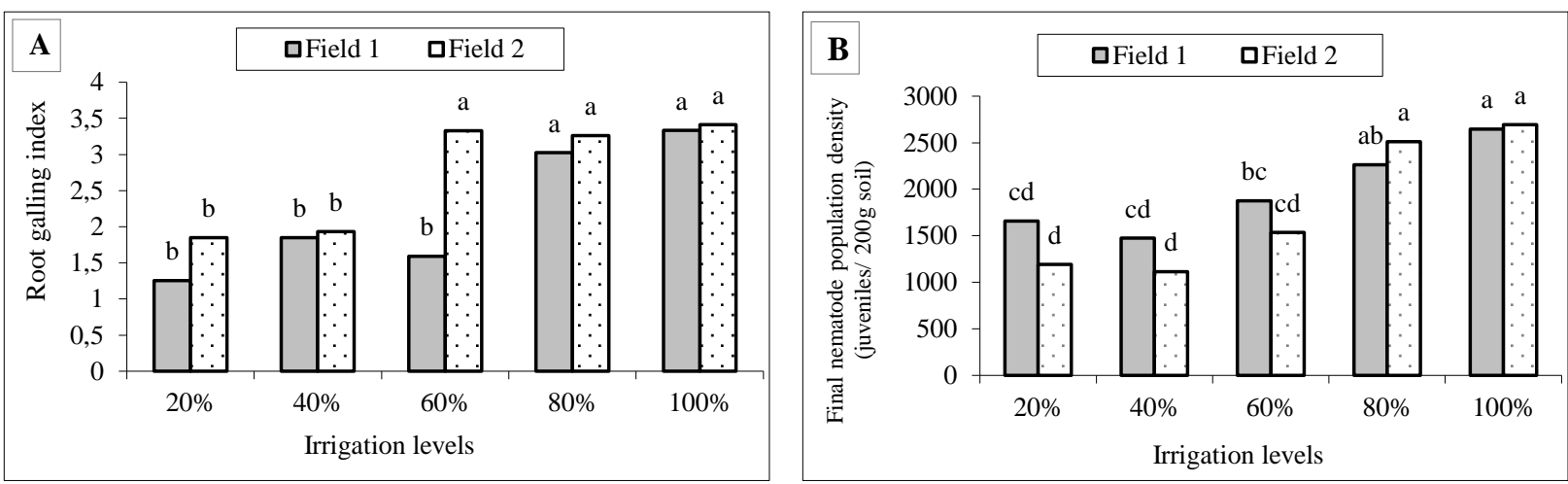

Fig. 1. Effects of different irrigation levels (20, 40, 60, 80 and 100\% of field capacity) on root galling (A) and final population density of Meloidogyne javanica in eggplant cultivation. Field 1 - Ghor es-Safi region, Field 2 - Karak Valley of Jordan. The means with the same letters on bars are not significantly different at 0.05 probability level using DMRT test 
Table 2. Main and interaction effects (probability values) of Meloidogyne javanica - infested fields (Ghor es-Safi or Karak Valley), and irrigation levels $(20,40,60,80$ and $100 \%$ of field capacity) on plant and nematode measured parameters

\begin{tabular}{lccccc}
\hline \multicolumn{1}{c}{ Source } & $\begin{array}{c}\text { Shoot dry } \\
\text { weight }\end{array}$ & Root dry weight & Fruit yield & $\begin{array}{c}\text { Root galling } \\
\text { index }\end{array}$ & $\begin{array}{c}\text { Final nematode } \\
\text { number }\end{array}$ \\
\hline \multirow{3}{*}{ Field } & $0.023^{*}$ & $0.000^{* * *}$ & $0.000^{* * *}$ & $0.802 \mathrm{~ns}$ & $0.343 \mathrm{~ns}$ \\
& 301488.0 & 43565.3 & 67527.1 & 11145.8 & 34672.0 \\
\hline \multirow{3}{*}{ Irrigation } & 1 & 1 & 1 & 1 & 1 \\
\hline \multirow{3}{*}{ Field X irrigation } & $0.001^{* *}$ & $0.403 \mathrm{~ns}$ & $0.000^{* * *}$ & $0.000^{* * *}$ & $0.046^{*}$ \\
& 40547.0 & 78584.1 & 78521.1 & 33386.0 & 10286.7 \\
\hline \multirow{3}{*}{ Blocks } & 4 & 4 & 4 & 4 & 4 \\
\hline & $0.363 \mathrm{~ns}$ & $0.089 \mathrm{~ns}$ & $0.108 \mathrm{~ns}$ & $0.243 \mathrm{~ns}$ & $0.875 \mathrm{~ns}$ \\
& 4 & 5687.0 & 1112.6 & 3465.9 & 3339.4 \\
& 0.0 & 4 & 4 & 4 & 4 \\
\hline
\end{tabular}

Means, mean squares and degrees of freedom are shown per each cell.

$*$, ** and *** are significant at $0.05,0.01$ and 0.001 probability levels.

Field as a main factor significantly $(\mathrm{p} \leq 0.05)$ affected shoot and root dry weights, and fruit yield of eggplant due to differences in soil properties and climatic conditions between the two fields studied, but did not affect root galling caused by the nematode or the final nematode population at the end of the eggplant growing season. However, irrigation as a main factor affected all the plant and nematode parameters, yet the interaction between the type of field and irrigation level was not significant (Table 2).

\section{DISCUSSION}

Today, irrigation/farm water delivery systems are the single largest consumer of water on the planet, but competition for water from other sectors will force agricultural production to use irrigation methods suited to operate under conditions of water scarcity, thus leading to adoption of deficit irrigation technique. By reducing water used for irrigation, farmers can cope with situations where water supply is restricted (Sharp et al. 1996; Fereres \& Soriano 2007). Greater reduction in plant growth occurred at deficit irrigation levels of 40 and $20 \%$ of $\mathrm{FC}$ than at 60 and $80 \%$, where root growth of eggplant was not greatly reduced under controlled environmental conditions (Mohawesh \& Karajeh
2014). Under open field conditions, growth of eggplant plants was greatly affected at irrigation levels of 40 and $20 \%$ of FC in one field location, but not at the other field location, which indicates that the influence of deficit irrigation is field-dependant, as there are some differences in soil properties and climatic conditions even when using the same irrigation level. Eggplant fruit yield was similar at all irrigation levels, except at $20 \%$ level, where a lower yield was noticed than the $100 \%$ level. By affecting plant growth, development, and carbon assimilation, water deficit may reduce the yield (Hsiao 1973). The reduction in yield at irrigation level of $20 \%$ of FC is caused by a decrease in biomass production (Kirnak et al. 2001). Furthermore, water productivity, which is the yield or net income per unit of water used in evapotranspiration (Kijne et al. 2003), is expected to increase under deficit irrigation relative to its value under full irrigation, as revealed experimentally for many crops (Tüzel et al. 1994a, b; Zwart \& Bastiaanssen 2004; Fan et al. 2005; Fereres \& Soriano 2007).

Water is a potential factor that affects the growth, development, and survival of nematodes (Prot 1979; Towson \& Apt 1983). In the present study, irrigation as the main factor affected nematode parameters, including eggplant infection in 
terms of root galling caused by the root-knot nematode $M$. javanica, and its reproduction. Root galling index of eggplant was much lower for plants irrigated at 20,40 and 60\% levels than those at 80 and $100 \%$ levels under one field condition, but plants irrigated at $60 \%$ level did not differ in the extent of root infection from plants irrigated at 80 and $100 \%$ levels in the other field conditions. Field as the main factor did not affect root galling caused by the nematode or the final nematode population at the end of the eggplant growing season. The final population of $M$. javanica was obviously lower in the rhizospheric soil of fields irrigated at 20,40 and $60 \%$ levels than that of fields irrigated at 80 and $100 \%$ levels under the two field conditions. Thus, deficit irrigation levels of 40 and $60 \%$ of FC can be used for the management of $M$. javanica without any negative impact on eggplant growth and yield under field conditions.

\section{Acknowledgement}

This work is a part of the research project financially supported by the Scientific Research Support Fund of the Ministry of Higher Education and Scientific Research of Jordan.

\section{REFERENCES}

Abu-Gharbieh W.I., Karajeh M.R., Masoud S.H. 2005. Current distribution of the root-knot nematodes (Meloidogyne species and races) in Jordan. Jordan Journal of Agricultural Sciences 1(1): 43-48.

Barker K.R., Carter C.C., Sasser J.N. 1985. An advanced treatise on Meloidogyne. Vol. II: Methodology. North Carolina State University Graphics, Raleigh, NC, USA, $223 \mathrm{p}$.

Duncan L.W., Inserra R.N., Dunn D. 1998. Seasonal changes in citrus fibrous root starch concentration and body length of female Pratylenchus coffeae. Nematropica 28(2): 263-266.

Fan T., Stewart B.A., Payne W.A., Wang Y., Song S., Luo J., Robinson C.A. 2005. Supplemental irrigation and water - yield relationships for plasticulture crops in the Loess Plateau of China. Agronomy Journal 97: 177-188.

Fereres E., Soriano M.A. 2007. Deficit irrigation for reducing agricultural water use. Journal of Experimental Botany 58(2): 147-159. DOI: 10.1093/jxb/erl165.
Geerts S., Raes D. 2009. Deficit irrigation as an on-farm strategy to maximize crop water productivity in dry areas. Agricultural Water Management 96(9):1275-1284. DOI: $\quad 10.1016 / \mathrm{j} . \mathrm{ag}-$ wat.2009.04.009.

Hsiao T.C. 1973. Plant responses to water stress. Annual Review of Plant Physiology 24: 519-570. DOI: 10.1146/annurev.pp.24.060173.002511.

Hunter J.J. 2000. Plant spacing effects on root growth and dry matter partitioning of Vitis vinifera cv. Pinot noir/99 Richter and implications for soil utilisation. Acta Horticulturae 526: 63-74. DOI: 10.17660/ActaHortic.2000.526.4.

Hussey R.S., Barker K.R. 1973. A comparison of methods of collecting inocula of Meloidogyne spp., including a new technique. Plant Disease Reporter 57: 1025-1038.

Karajeh M.R. 2004. Identification, distribution, and genetic variability of the root-knot nematodes (Meloidogyne spp.) in Jordan. Ph.D. Thesis, University of Jordan, Amman, Jordan, $152 \mathrm{p}$.

Karajeh M.R., Al-Ameiri N.S. 2010. A survey of plantparasitic nematodes in Karak Province of Jordan. Dirasat, Agricultural Sciences 37(2): 77-81.

Khyami-Horani H., Al-Banna L. 2006. Efficacy of Bacillus thuringiensis jordanica against Meloidogyne javanica infecting tomato. Phytopathologia Mediterranea 45(2): 153-157. DOI: 10.14601/Phytopathol_Mediterr-1826.

Kijne J.W., Barker R., Molden D.J. 2003. Water productivity in agriculture: limits and opportunities for improvement. Wallingford, UK: CABI Pub., 352 p. DOI: $10.1079 / 9780851996691.0000$.

Kirnak H., Kaya C., Tas I., Higgs D. 2001. The influence of water deficit on vegetative growth, physiology, fruit yield and quality in eggplant. Bulgarian Journal of Plant Physiology 27(3-4): 34-46.

Kriedemann P.E., Goodwin I. 2009. Regulated deficit irrigation and partial root-zone drying: An overview of principles and applications. Land \& Water, Australia, $102 \mathrm{p}$.

Mahadeen A.Y., Mohawesh O.E., Al-Absi K., Al-Shareef W. 2011. Effect of irrigation regimes on water use efficiency and tomato yield (Lycopersicon esculentum Mill.) grown in an arid environment. Archives of Agronomy and Soil Science 57(1): 105-114. DOI: 10.1080/03650340903225024.

Mohawesh O., Karajeh M. 2014. Effects of deficit irrigation on tomato and eggplant and their infection with the root-knot nematode under controlled environmental conditions. Archives of Agronomy 
and Soil Science 60(8): 1091-1102. DOI: $10.1080 / 03650340.2013 .871385$.

Prot J.C. 1979. Horizontal migrations of second-stage juveniles of Meloidogyne javanica in sand in concentration gradients of salts and in a moisture gradient. Revue Nematologie 2: 17-21.

Sasser J. 1987. A perspective on nematode problems worldwide. pp. 1-12. In: Proceedings Nematodes Parasitic to Cereals and Legumesin Temperature Semiarid Regions, Larnaca, Cyprus. ICARDA, Aleppo, Syria.

Sasser, J., D. Freckman. 1987. A world perspective on nematology: The role of the society. pp. 7-14. In: Veech J. and Dickson D. (eds). Vistas on Nematology. Society of Nematologists, Hyattsville, Maryland. 509 pp.

Sasser J., Eisenback J., Carter C., Triantaphyllou A. 1983. The international Meloidogyne project: Its goals and accomplishments. Annual Review of Phytopathology 21: 271-288.

Sharp R., Boyer J.S., Nguyen H.T., Hsiao T.C. 1996. Genetically engineered plants resistant to soil drying and salt stress: How to interpret osmotic relations. Plant Physiology 110(4): 1051-1053. DOI: 10.1104/pp.110.4.1051.

Shin S.H. 2005. Effect of irrigation systems, partial root zone drying irrigation and regulated deficit on plant parasitic nematode populations in grapevine. M. Sc. Thesis. The University of Western Australia, $75 \mathrm{p}$.

Siddiqui I.A., Shaukat S.S., Khan G.H., Ali N.I. 2003. Suppression of Meloidogyne javanica by Pseudomonas aeruginosa $\mathrm{IE}-6 \mathrm{~S}^{+}$in tomato: the influence of $\mathrm{NaCl}$, oxygen supply and iron levels. Soil Biology and Biochemistry 35(12): 1625-1634. DOI: 10.1016/j.soilbio.2003.08.007.

Strajnar P., Širca S., Urek G., Šircelj H., Železnik P., Vodnik D. 2012. Effect of Meloidogyne ethiopica parasitism on water management and physiological stress in tomato. European Journal of Plant Pathology 132(1): 49-57. DOI: 10.1007/s10658-0119847-6.

Taylor A.L., Sasser J.N. 1978. Biology, identification and control of root-knot nematodes (Meloidogyne spp.). North Carolina State University Graphic, Raleigh, NC, USA, $111 \mathrm{p}$.

Towson A.J., Apt W.J. 1983. Effects of soil water potential on survival of Meloidogyne javanica in fallow soil. Journal of Nematology 15(1):110-115.

Tüzel I.H., Ul M.A., Tüzel Y. 1994a. Effects of different irrigation intervals and rates on spring-season glasshouse tomato production: I. Yield and plant growth. Acta Horticulturae 366: 381-388. DOI: 10.17660/ActaHortic.1994.366.47

Tüzel Y., Ul M.A., Tüzel I.H. 1994b. Effects of different irrigation intervals and rates on spring season glasshouse tomato production: II. Fruit quality. Acta Horticulturae 366: 389-396. DOI: 10.17660/ActaHortic.1994.366.48.

Wallace H.R. 1963. Biology of plant parasitic nematodes. Edward Arnold Ltd., London, 280 p.

Whitehead A.G., Hemming J.R. 1965. A comparison of some quantitative methods for extracting small vermiform nematodes from soil. Annals of Applied Biology 55(1): 25-38. DOI: $10.1111 / \mathrm{j} .1744-$ 7348.1965.tb07864.x.

Zegbe J.A., Behboudian M.H., Clothier B.E. 2004. Partial rootzone drying is a feasible option for irrigating processing tomatoes. Agricultural Water Management 68: 195-206. DOI: 10.1016/j.agwat.2004.04.002.

Zwart S.J., Bastiaanssen W.G.M. 2004. Review of measured crop water productivity values for irrigated wheat, rice, cotton and maize. Agricultural Water Management 69(2): 115-133. DOI: 10.1016/j.agwat.2004.04.007. 